\title{
Cardiac Remodeling Induced by All-Trans Retinoic Acid is Detrimental in Normal Rats
}

\author{
Renata A. C. Silva ${ }^{a}$ Andréa F. Gonçalves ${ }^{a}$ Priscila P. dos Santos ${ }^{a} \quad$ Bruna Rafacho $^{a}$ \\ Renan F. T. Claro ${ }^{a}$ Marcos F. Minicuccia Paula S. Azevedo ${ }^{a}$ Bertha F. Polegato ${ }^{a}$ \\ Silméia G. Zanatia ${ }^{a}$ Ana Angélica Fernandes ${ }^{\mathrm{b}}$ Sergio A. R. Paiva ${ }^{\mathrm{a}}$ \\ Leonardo A. M. Zornoffa
}

aSão Paulo State University (Unesp), Botucatu Medical School, Internal Medicine Department, Botucatu, bSão Paulo State University (Unesp), Institute of Biosciences of Botucatu, Chemistry and Biochemistry

Department, Botucatu, Brazil

\section{Key Words}

Hypertrophy • Cardiac function • Retinoic acid • Energy metabolism

\begin{abstract}
Background/Aims: This study aimed to discern whether the cardiac alterations caused by retinoic acid (RA) in normal adult rats are physiologic or pathologic. Methods and Results: Wistar rats were assigned into four groups: control animals $(C, n=20)$ received a standard rat chow; animals fed a diet supplemented with $0.3 \mathrm{mg} / \mathrm{kg} /$ day all-trans-RA (AR1, $\mathrm{n}=20$ ); animals fed a diet supplemented with $5 \mathrm{mg} / \mathrm{kg} /$ day all-trans-RA (AR2, $\mathrm{n}=20$ ); and animals fed a diet supplemented with $10 \mathrm{mg} / \mathrm{kg} /$ day all-trans-RA (AR3, $\mathrm{n}=20$ ). After 2 months, the animals were submitted to echocardiogram, isolated heart study, histology, energy metabolism status, oxidative stress condition, and the signaling pathway involved in the cardiac remodeling induced by RA. RA increased myocyte cross-sectional area in a dose-dependent manner. The treatment did not change the morphological and functional variables, assessed by echocardiogram and isolated heart study. In contrast, RA changed catalases, superoxide dismutase, and glutathione peroxidases and was associated with increased values of lipid hydroperoxide, suggesting oxidative stress. RA also reduced citrate synthase, enzymatic mitochondrial complex II, ATP synthase, and enzymes of fatty acid metabolism and was associated with increased enzymes involved in glucose use. In addition, RA increased JNK 1/2 expression, without changes in TGF- $\beta$, PI3K, AKT, NFKB, S6K, and ERK. Conclusion: In normal rats, RA induces cardiac hypertrophy in a dose-dependent manner. The non-participation of the PI3K/Akt pathway, associated with the participation of the JNK pathway, oxidative stress, and changes in energy metabolism, suggests that cardiac remodeling induced by RA supplementation is deleterious.




\section{Introduction}

Retinoic acid (RA), an active metabolite of vitamin A that acts through nuclear retinoid receptors, influences gene expression, alters the synthesis of proteins in the heart, and regulates embryonic development, tissue homeostasis, and cellular differentiation and proliferation [1-3].

Experimental studies suggest that RA plays a critical role in regulating cardiac structure and function throughout life [4]. During early stages of cardiogenesis, RA excess produces congenital defects related to abnormal folding and septation of the outflow tract and cardiac chambers [5]. Likewise, excess of RA signaling (overexpression of RA receptor or retinoid X receptor) results in cardiomyocyte abnormalities and dilated cardiomyopathy [6-8]. In contrast, vitamin A-deficient animals and receptor knockout models have thin myocardial walls, and the embryos develop a generalized edema associated with heart failure [9].

The effects of RA in the adult period are still poorly understood. All-trans-RA (ATRA) attenuated hypoxia-induced injury in renal cells [10]. RA may modulates collagen synthesis via TGF- $\beta$ [11]. During cardiac injuries, experimental studies have shown that ATRA inhibits hypertrophy and fibrosis in spontaneously hypertensive rats [12], during exposure to tobacco smoke [13], after myocardial infarction [14, 15], in aortic-banded rats [16], and after carotid injury [17]. Therefore, RA attenuates cardiac remodeling following different insults.

Our research group studied the effects of RA supplementation in normal rats. RA supplemented at a physiologic dose, in rats without any type of cardiovascular aggression, caused cardiac remodeling with left ventricular hypertrophy, without interstitial fibrosis, and maintenance of cardiac geometry and function [18]. Importantly, this pattern is found in both physiologic (isotonic exercise) and pathologic (compensated volume overload) conditions. We also studied patients using 13-cys-RA for acne treatment [19]. These patients showed increase in relative wall thickness and in left ventricle (LV) mass, without changes in cardiac function after 10 weeks of treatment. Thus, the doubt about physiologic or pathologic remodeling induced by RA supplementation still remains. In this manner, this study aimed to discern whether the cardiac alterations caused by RA in normal adult rats are physiologic or pathologic. Therefore, we analyzed the energy metabolism status, oxidative stress condition, and the signaling pathway involved in the cardiac remodeling induced by RA.

\section{Materials and Methods}

All experiments and procedures were performed in accordance with the National Institute of Health's Guide for the Care and Use of Laboratory Animals and were approved by the Animal Ethics Committee of Botucatu Medical School.

Wistar rats, weighing approximately $250 \mathrm{~g}$, were randomly assigned into four groups: control animals (C, $n=20$ ) received a standard rat chow; animals fed a diet supplemented with $0.3 \mathrm{mg} / \mathrm{kg} / \mathrm{day}$ all-trans-RA (AR1, $n=20$ ); animals fed a diet supplemented with $5 \mathrm{mg} / \mathrm{kg} /$ day all-trans-RA (AR2, $n=20$ ); and animals fed a diet supplemented with $10 \mathrm{mg} / \mathrm{kg} /$ day all-trans-RA (AR3, $n=20$ ). All animals were housed in individual cages in a room maintained at $23^{\circ} \mathrm{C}$ on a $12: 12$-h light-dark cycle. The planned observation period was 2 months.

\section{Echocardiographic study}

Before death, all animals were weighed and evaluated with the use of transthoracic echocardiography. The exams were performed with the use of a commercially available echocardiogram (General Eletric Medical System modelo Vivid S6 - Tirat Carml, Israel) equipped with a 5.0-11.5-MHz phased-array transducer. Imaging was performed with the use of a $60^{\circ}$ sector angle and $3-\mathrm{cm}$ imaging depth. Rats were lightly anesthetized by intramuscular injection with a mixture of ketamine ( $50 \mathrm{mg} / \mathrm{kg}$ ) and xylazine (1 mg/ $\mathrm{kg}$ ). After the chest was shaved, the rats were placed in left lateral recumbency.

Targeted two-dimensional M-mode echocardiograms were obtained from short-axis views of the LV at or just below the tip of the mitral-valve leaflets and at the level of aortic valve and left atrium. M-mode images 


\section{Cellular Physiology Cell Physiol Biochem 2017;43:1449-1459



Silva et al.: Retinoic Acid and Ventricular Remodeling

of the LV, left atrium, and aorta were recorded on a black-and-white thermal printer (model Up-890MD, Sony) at a sweep speed of $100 \mathrm{~mm} / \mathrm{s}$. All tracings were manually measured with a caliper by the same observer, according to the leading-edge method recommended by the American Society of Echocardiography [20]. Measurements represented the mean of at least five consecutive cardiac cycles. LV end-diastolic dimension (LVEDD) and posterior wall thickness were measured at maximal diastolic dimension, and the LV endsystolic dimension (LVSD) was measured at the point of maximal anterior motion of posterior wall. LV systolic function was assessed by calculation of the fractional shortening index [(LVEDD-LVSD)/LVEDD $\times$ 100]. Left atrium was measured at its maximal diameter and aorta at end of diastole. Echocardiographic LV mass was calculated by using the standard cube function formula. The velocity of diastolic flow through the mitral valve (E and A wave velocities) was obtained in the apical four-chamber view. The E/A ratio was used as an index of LV diastolic function [21].

\section{Isolated heart study}

After the echocardiographic study, rats were anesthetized with thiopental sodium $(50 \mathrm{mg} / \mathrm{kg}$, intraperitoneally i.p.) and given heparin (2000 UI, i.p.). The chest was opened by median sternotomy under artificial ventilation. The ascending aorta was isolated and cannulated for retrograde perfusion. The heart was quickly removed and transferred to a perfusion apparatus (model 830 Hugo Sachs EletronickGreen-Strasse). Retrograde perfusion was established with filtered oxygenated Krebs-Henseleit solution (composition, in mmol/L: $\mathrm{NaCl} 118.5$; $\mathrm{KCl}$ 4.69; $\mathrm{CaCl} 2$ 2.52; MgSO4 1.16; $\mathrm{KH} 2 \mathrm{PO} 4$ 1.18; glicose 5.50; NaHCO3 25.88; and mannitol), maintained at constant temperature $\left(37^{\circ} \mathrm{C}\right)$ and perfusion pressure $(75$ $\mathrm{mmHg}$ ). All hearts were paced at 200 to 250 beats/min. Latex balloon was inserted in $\mathrm{LV}$, and the volume inside the balloon was increased progressively. Pressure values, maximum LV pressure decrease rate, and maximum LV pressure development rate were recorded. Procedures and measurements were performed according to a previously described method [22-24].

\section{Morphometric analysis}

At the completion of the functional study, the right ventricle (RV) and LV (including the interventricular septum) were dissected, separated, and weighed.

Morphometric analysis of the myocardium was performed as described previously [25]. Myocyte crosssectional area (CSA) was determined for at least 50 myocytes per slide stained with hematoxylin-eosin. The measurements were performed using a Leica microscope ( $\times 400$ magnification) attached to a video camera and connected to a personal computer equipped with image analyzer software (Image-Pro Plus 3.0, Media Cybernetics, Silver Spring, MD, USA). CSA was measured with a digitizing pad, and the selected cells were transversely cut with the nucleus clearly identified in the center of the myocyte. Interstitial collagen volume fraction (IC) was determined for the entire picrosirius-red-stained cardiac section using an automated image analyzer (Image-Pro Plus 3.0, Media Cybernetics). On average, 35 microscopic fields were analyzed with $\times 40$ magnification. Perivascular collagen was excluded from this analysis. All measurements were performed by the same observer who was blinded to treatment assignment.

\section{Energy metabolism and oxidative stress}

The LV samples of $100 \mathrm{mg}$ from eight animals in each group were used for the measurements of the amount of total protein and lipid hydroperoxide (LH) and for the enzyme determinations. Glutathione peroxidase (GSHPx, E.C.1.11.1.9), superoxide dismutase (SOD, E.C.1.15.1.1), and catalase (CAT, E.C.1.11.1.6) activity was assessed as previously specified [26]. The cardiac energy metabolism was assessed with 3-hydroxyacyl coenzyme-A dehydrogenase (OHADH, E.C.1.1.1.35.) and lactate dehydrogenase (LDH, E.C.1.1.1.27) and citrate synthase (CS; E.C.4.1.3.7.) activities, as previously described [27]. Enzyme activities were determined with a temperature-controlled microplate reader (Eon with Gen5 2.0 software connected to computer system control, BioTek Instruments, Winooski, VT, USA). All of the reagents were from Sigma (St. Louis, MO, USA).

\section{Western Blot analysis}

LV samples were extracted using Tris-Triton buffer (10 mM Tris (pH 7.4), $100 \mathrm{mM} \mathrm{NaCl,} 1 \mathrm{mM}$ EDTA, 1 mM EGTA, 1\% Triton X-100, 10\% glycerol, 0.1\% SDS, 0.5\% deoxycholate, 1 nM EDTA, 1 mM EGTA, and a mixture of protease inhibitors, $1 \mathrm{mM}$ sodium orthovanadate, $1 \mathrm{mM}$ sodium fluoride, and $1 \%$ leupeptin, 


\section{Cellular Physiology Cell Physiol Biochem 2017;43:1449-1459 \begin{tabular}{l|l|l}
\hline and Biochemistry 10.1159/000481876 & $\begin{array}{l}\text { C } 2017 \text { The Author(s). Published by S. Karger AG, Basel } \\
\text { www.karger.com/cpb }\end{array}$ \\
\hline
\end{tabular}

aprotinin, pepstatin) to detect total and phospho $\mathrm{NF \kappa B}$, total and phospho Akt, total and phospho PI3K, total and phospho S6K, ERK, and JNK 1/2. The samples were then centrifuged at $12,000 \mathrm{rtm}$ at $4{ }^{\circ} \mathrm{C}$ for 20 min, and the supernatant was collected. The supernatant protein content was quantified using the Bradford method. The samples were separated on a $10 \%$ SDS-polyacrylamide gel, and the proteins were transferred to a nitrocellulose membrane. The membrane was blocked with $5 \%$ nonfat dry milk in Tris-buffered saline containing Tris $1 \mathrm{M}(\mathrm{pH} \mathrm{8.0)}, \mathrm{NaCl} 5 \mathrm{M}$, and Tween 20 at room temperature for $2 \mathrm{~h}$. The membrane was then incubated with the following antibodies: primary antibody anti-NFKB, mouse monoclonal (Santa Cruz Biotechnology, Inc, Europe, sc-8008); anti-phospho-NFKB, rabbit polyclonal (Santa Cruz Biotechnology, sc33020); anti-Akt rabbit polyclonal (Cell Signaling Technology, \#9272); anti-phospho-Akt rabbit monoclonal (Cell Signaling Technology, \#4060); anti-PI3K, mouse monoclonal (Santa Cruz Biotechnology, sc-1637); anti-phospho-PI3K, goat polyclonal (Santa Cruz Biotechnology, sc-12929); anti-S6K1, rabbit monoclonal (Abcam, ab32529); anti-phospho-S6K1, rabbit polyclonal (Abcam, ab5231); anti-ERK, rabbit policlonal (Santa Cruz Biotechnology, sc-93); and anti-JNK1/2, mouse monoclonal (Santa Cruz Biotechnology, sc137019). The membrane was washed with TBS and Tween 20 and incubated with the appropriate secondary peroxidase-conjugated antibody. A Super Signal West Pico Chemiluminescent Substrate (Pierce Protein Research Products, Rockford, IL, USA) was used to detect bound antibodies. GAPDH (GAPDH (6C5), mouse monoclonal IgG1 (Santa Cruz Biotechnology, sc 32233), was used for normalization.

\section{Statistical analysis}

The comparisons between groups were made by one-way analysis of variance (ANOVA) test complemented by the Tukey test, when the data were normally distributed. When the data presented an abnormal distribution, the Kruskal-Wallis test was complemented by the Dunn test. The Spearman test was used to evaluate whether the effect of RA is dose-dependent. Data were expressed as mean \pm SD or medians (including the lower quartile and upper quartile). Data analysis was performed with SigmaStat for Windows v3.5 (SPSS Inc, Chicago, IL, USA). The significance level used was 5\%.

\section{Results}

The echocardiographic data are shown in Table 1. RA did not change morphological or functional variables. However, there is a trend to increased LV mass with the treatment. Likewise, in the isolated heart study, there are no functional differences among the groups. (Table 2).

Table 1. Echocardiographic data, LV: left ventricle; LVDD: LV end-diastolic dimension; BW: body weight; LVSD: LV end-systolic dimension; LVMI: LV mass index; E/A: ratio between early (E) and late (atrial-A) ventricular filling velocity; EF: ejection fraction; HR: heart rate. Data are expressed as mean \pm SD or medians (including the lower quartile and upper quartile)

\begin{tabular}{|c|c|c|c|c|c|c|}
\hline Variables & $\begin{array}{l}\text { Control } \\
(n=15)\end{array}$ & $\begin{array}{c}\text { AR1 }(0.3 \mathrm{mg} / \mathrm{kg} / \text { day }) \\
(\mathrm{n}=15)\end{array}$ & $\begin{array}{c}\text { AR2 } \\
(5 \mathrm{mg} / \mathrm{kg} / \text { day }) \\
(\mathrm{n}=15)\end{array}$ & $\begin{array}{c}\text { AR3 } \\
(10 \mathrm{mg} / \mathrm{kg} / \text { day }) \\
(\mathrm{n}=15)\end{array}$ & $\mathrm{p}$ & pTrend \\
\hline LVDD (mm) & $7.12 \pm 0.51$ & $7.51 \pm 0.63$ & $7.33 \pm 0.76$ & $7.46 \pm 0.67$ & 0.422 & 0.312 \\
\hline LVDD/BW (mm/kg) & $16.8 \pm 1.63$ & $17.8 \pm 1.67$ & $17.3 \pm 1.7$ & $17.7 \pm 1.45$ & 0.434 & 0.289 \\
\hline LVSD (mm) & $3.35 \pm 0.63$ & $3.56 \pm 0.64$ & $3.47 \pm 0.54$ & $3.57 \pm 0.48$ & 0.432 & 0.291 \\
\hline LVMI (g/kg) & $2.10 \pm 0.1$ & $1.99 \pm 0.1$ & $2.09 \pm 0.1$ & $2.11 \pm 0.10$ & 0.115 & 0.073 \\
\hline $\mathrm{E} / \mathrm{A}$ & $1.67 \pm 0.31$ & $1.73 \pm 0.24$ & $1.66 \pm 0.27$ & $1.69 \pm 0.40$ & 0.684 & 0.312 \\
\hline $\mathrm{EF}(\%)$ & $0.97 \pm 0.03$ & $0.95 \pm 0.03$ & $0.98 \pm 0.03$ & $0.95 \pm 0.02$ & 0.770 & 0.441 \\
\hline HR (beats/min) & $298 \pm 45.4$ & $288 \pm 60.4$ & $284 \pm 33.7$ & $293 \pm 44.0$ & 0.856 & 0.722 \\
\hline
\end{tabular}


Table 2. Isolated heart data, $+\mathrm{dP} / \mathrm{dt}$ : maximum $\mathrm{LV}$ pressure development rate; $-\mathrm{dP} / \mathrm{dt}$ : maximum LV pressure decrease rate. SP: systolic pressure. Data are expressed as mean \pm SD or medians (including the lower quartile and upper quartile)

\begin{tabular}{|c|c|c|c|c|c|c|}
\hline Variables & $\begin{array}{l}\text { Control } \\
(n=8)\end{array}$ & $\begin{array}{c}\text { AR1 } \\
(0.3 \mathrm{mg} / \mathrm{kg} / \text { day }) \\
(\mathrm{n}=8)\end{array}$ & $\begin{array}{c}\text { AR2 } \\
(5 \mathrm{mg} / \mathrm{kg} / \text { day }) \\
(\mathrm{n}=8)\end{array}$ & $\begin{array}{c}\text { AR3 } \\
(10 \mathrm{mg} / \mathrm{kg} / \text { day }) \\
(\mathrm{n}=8)\end{array}$ & $p$ & pTrend \\
\hline$+\mathrm{dP} / \mathrm{dt}(\mathrm{mmHg} / \mathrm{s})$ & $2910 \pm 543$ & $2839 \pm 652$ & $2541 \pm 595$ & $2910 \pm 619$ & 0.667 & 0.774 \\
\hline$-\mathrm{dP} / \mathrm{dt}(\mathrm{mmHg} / \mathrm{s})$ & $2428 \pm 509$ & $2160 \pm 373$ & $1875 \pm 379$ & $2339 \pm 607$ & 0.207 & 0.504 \\
\hline SP (mmHg) & $134 \pm 15.3$ & $125 \pm 13.3$ & $110 \pm 15.4$ & $131 \pm 18.9$ & 0.065 & 0.392 \\
\hline
\end{tabular}

Table 3. Morphologic data, BW: body weight; LVW: left ventricular weight; RVW: right ventricular weight; CSA: cross-sectional area; IC: interstitial collagen volume fraction. Data are expressed as mean \pm SD or medians (including the lower quartile and upper quartile). ${ }^{*} \mathrm{p}<0.05$ vs control. \# $\mathrm{p}<0.05$ vs AR1. \& $\mathrm{p}<0.05$ vs AR2

\begin{tabular}{|c|c|c|c|c|c|c|}
\hline Variables & $\begin{array}{l}\text { Control } \\
(n=12)\end{array}$ & $\begin{array}{c}\text { AR1 } \\
(0.3 \mathrm{mg} / \mathrm{kg} / \text { day }) \\
(\mathrm{n}=14)\end{array}$ & $\begin{array}{c}\text { AR2 } \\
(5 \mathrm{mg} / \mathrm{kg} / \text { day }) \\
(\mathrm{n}=13)\end{array}$ & $\begin{array}{c}\text { AR3 } \\
(10 \mathrm{mg} / \mathrm{kg} / \text { day }) \\
(\mathrm{n}=13)\end{array}$ & $\mathrm{p}$ & pTrend \\
\hline BW (g) & $425 \pm 11$ & $423 \pm 13$ & $423 \pm 13$ & $422 \pm 13$ & 0.929 & 0.531 \\
\hline LVW (g) & $0.82 \pm 0.06$ & $0.83 \pm 0.06$ & $0.82 \pm 0.06$ & $0.87 \pm 0.05$ & 0.172 & 0.090 \\
\hline LVW/BW (g/kg) & $1.98 \pm 0.08$ & $1.95 \pm 0.13$ & $1.98 \pm 0.13$ & $2.07 \pm 0.15$ & 0.115 & 0.070 \\
\hline RVW (g) & $0.21 \pm 0.03$ & $0.22 \pm 0.04$ & $0.20 \pm 0.03$ & $0.22 \pm 0.02$ & 0.331 & 0.599 \\
\hline $\operatorname{CSA}\left(\mu \mathrm{m}^{2}\right)$ & $137 \pm 3.27$ & $152 \pm 5.38$ & $161 \pm 7.71 *$ & $216 \pm 6.68^{*} \# \&$ & $<0.001$ & $<0.0001$ \\
\hline IC $(\%)$ & $5.2 \pm 0.4$ & $4.8 \pm 0.3$ & $5.0 \pm 0.4$ & $5.0 \pm 0.6$ & 0.254 & 0.425 \\
\hline
\end{tabular}

The results of the morphometric study are shown in Table 3. There are no differences among the groups considering BW, LVW, LVW/BW ratio, RVW, and IC. On the other hand, RA induced increased CSA, in a dose-response manner (Fig. 1).

The energy metabolism data are shown in Fig. 2. RA decreased ATP synthase (Fig. 2-A), PI-DH (Fig. 2-C), CS (Fig. 2-D), $\beta-\mathrm{OH}-$ acil CoA-DH (Fig. 2-E), and enzymatic mitochondrial complex II (Fig. 2-F), in a dose-response manner. On the other hand, the treatment with RA was associated with increase in PKF values (Fig. 2-B), in a doseresponse manner.

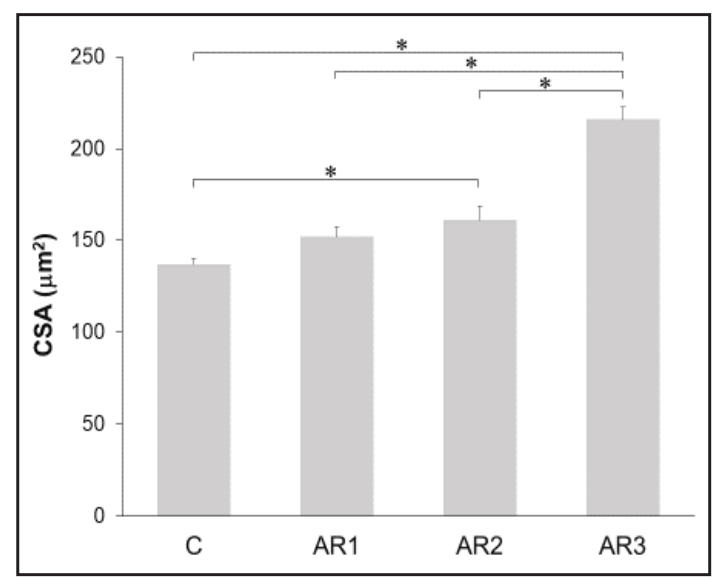

Fig. 1. CSA: cross-sectional area. * indicate statistically significant difference $(\mathrm{p}<0.05)$. 


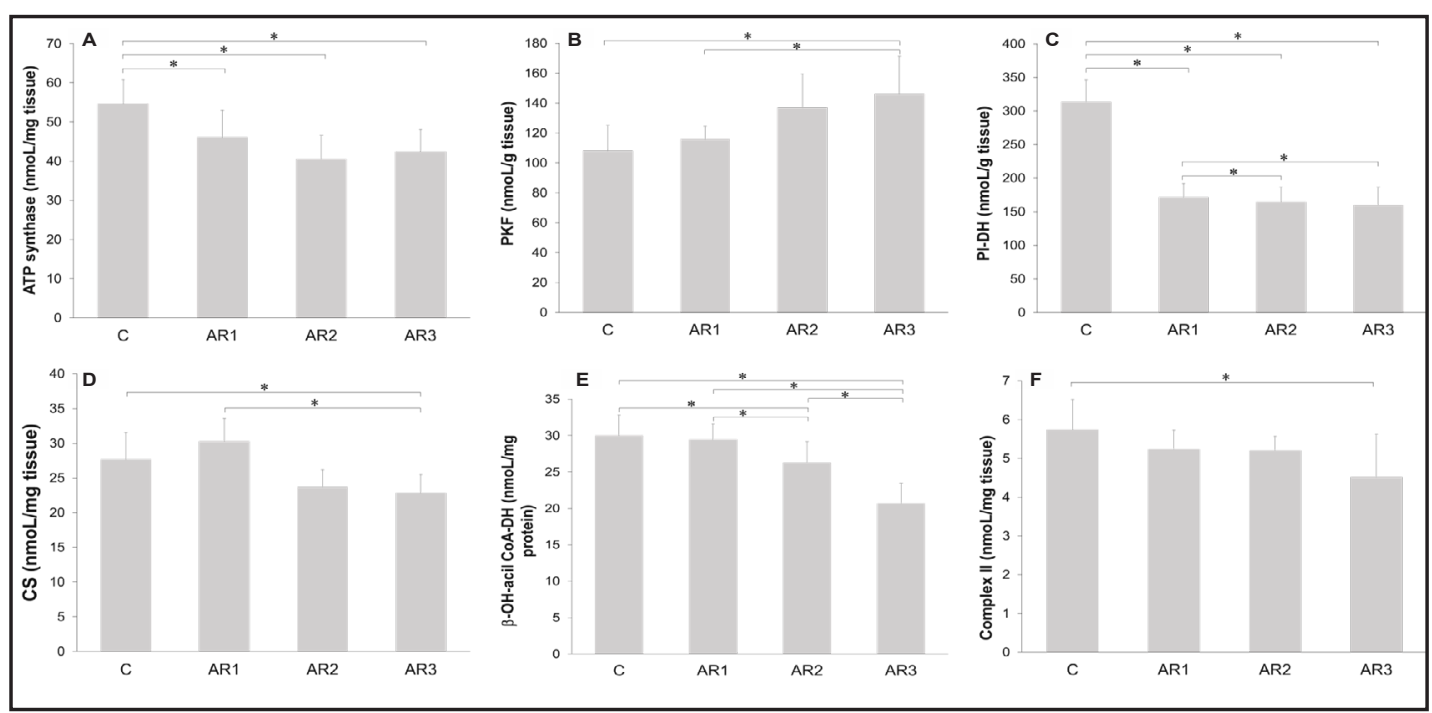

Fig. 2. Energy metabolism variables. * indicate statistically significant difference $(\mathrm{p}<0.05)$.

Table 4. Oxidative stress, SOD: superoxide dismutase; GSH-PX: glutathione peroxidases; LH: lipid hydroperoxide. Data are expressed as mean \pm SD or medians (including the lower quartile and upper quartile). ${ }^{*} \mathrm{p}<0.05$ vs control. \# $\mathrm{p}<0.05$ vs AR1

\begin{tabular}{|c|c|c|c|c|c|c|}
\hline Variables & $\begin{array}{l}\text { Control } \\
(\mathrm{n}=8)\end{array}$ & $\begin{array}{c}\text { AR1 } \\
(0.3 \mathrm{mg} / \mathrm{kg} / \text { day }) \\
(\mathrm{n}=8)\end{array}$ & $\begin{array}{c}\text { AR2 } \\
(5.0 \mathrm{mg} / \mathrm{kg} / \text { day }) \\
(\mathrm{n}=8)\end{array}$ & $\begin{array}{c}\text { AR3 } \\
(10 \mathrm{mg} / \mathrm{kg} / \text { day }) \\
(\mathrm{n}=8)\end{array}$ & $\mathrm{p}$ & pTrend \\
\hline $\begin{array}{l}\text { SOD (nmol/mg } \\
\text { protein) }\end{array}$ & $12 . \pm 1.46$ & $9.90 \pm 0.97^{*}$ & $8.88 \pm 0.81^{*}$ & $9.81 \pm 1.19 *$ & $<0.001$ & $<0.0001$ \\
\hline $\begin{array}{l}\text { GSH-Px }(\mathrm{nmol} / \mathrm{mg} \\
\text { tissue })\end{array}$ & $\begin{array}{l}45.0 \pm \\
4.88\end{array}$ & $33.5 \pm 4.53^{*}$ & $32.9 \pm 5.75^{*}$ & $26.3 \pm 4.21 * \#$ & $<0.001$ & $<0.0001$ \\
\hline $\begin{array}{l}\text { Catalase }(\mu \mathrm{moL} / \mathrm{g} \\
\text { tissue })\end{array}$ & $\begin{array}{l}71.3 \pm \\
8.29\end{array}$ & $128 \pm 15.8^{*}$ & $129 \pm 27.2^{*}$ & $\begin{array}{c}125.18 \pm \\
15.45^{*}\end{array}$ & $<0.001$ & $<0.0001$ \\
\hline LH (nmoL/g tissue) & $\begin{array}{l}183 \pm \\
19.2\end{array}$ & $211 \pm 30.8$ & $214 \pm 28.9$ & $229 \pm 11.3 * \#$ & 0.006 & 0.0008 \\
\hline
\end{tabular}

The results of oxidative stress are shown in Table 4. RA decreased the antioxidant enzymes SOD and GSH-Px, associated with an increase in CAT. In consequence, the treatment induced oxidative stress, demonstrated by the high values of LH.

The hypertrophy signaling pathway data are shown in Table 5. RA increased JNK expression (Fig. 3). In contrast, there are no differences in the other variables.

\section{Discussion}

The aim of this study was to discern whether the cardiac alterations caused by RA in normal adult rats are physiologic or pathologic. Our results showed that RA induced 
Table 5. Western blot proteins, Data are expressed as mean \pm SD or medians (including the lower quartile and upper quartile). ${ }^{*} \mathrm{p}<0.05$ vs control. \# p<0.05 vs AR1

\begin{tabular}{|c|c|c|c|c|c|c|}
\hline Variable & $\begin{array}{c}C \\
(n=13)\end{array}$ & $\begin{array}{c}\text { AR1 } \\
(0.3 \mathrm{mg} / \mathrm{kg} / \text { day }) \\
(\mathrm{n}=12)\end{array}$ & $\begin{array}{c}\text { AR2 } \\
(5 \mathrm{mg} / \mathrm{kg} / \text { day }) \\
(\mathrm{n}=12)\end{array}$ & $\begin{array}{c}\text { AR3 } \\
(10 \mathrm{mg} / \mathrm{kg} / \text { day }) \\
(\mathrm{n}=12)\end{array}$ & $\mathrm{p}$ & pTrend \\
\hline $\mathrm{pNkfb} / \mathrm{Nfkb}$ & $1.06(0.68-1.65)$ & $0.73(0.07-1.05)$ & $0.77(0.13-0.92)$ & $0.86(0.18-1.21)$ & 0.223 & 0.518 \\
\hline pAkt/Akt & $0.86(0.53-1.46)$ & $0.84(0.49-1.33)$ & $0.70(0.53-0.98)$ & $1.10(0.79-1.38)$ & 0.246 & 0.804 \\
\hline pS6k/S6k & $1.14(0.74-1.50)$ & $0.86(0.698-1.8)$ & $0.97(0.56-1.38)$ & $0.68(0.30-1.07)$ & 0.255 & 0.081 \\
\hline ERK & $0.92(0.74-1.16)$ & $1.09(0.67-1.31)$ & $0.73(0.52-1.31)$ & $1.15(0.72-1.71)$ & 0.449 & 0.270 \\
\hline pPI3K/PI3K & $0.96(0.68-1.36)$ & $0.98(0.56-1.70)$ & $0.84(0.77-1.16)$ & $1.23(0.41-1.81)$ & 0.968 & 0.646 \\
\hline TGF- $\beta$ & $1.94 \pm 0.48$ & $2.07 \pm 1.01$ & $2.01 \pm 0.47$ & $2.89 \pm 1.15$ & 0.836 & 0.415 \\
\hline JNK & $1.00 \pm 0.50$ & $0.99 \pm 0.49$ & $1.29 \pm 0.54$ & $1.59 \pm 0.52 * \#$ & 0.024 & 0.004 \\
\hline
\end{tabular}

Fig. 3. JNK expression in myocardial tissue, values presented as mean \pm SD. Protein levels were normalized to GAPDH levels. * indicate statistically significant difference $(p<0.05)$.

myocardial hypertrophy with changes in energy metabolism, increased oxidative stress, and produced alterations in pathologic pathways of hypertrophy, characteristic of deleterious cardiac remodeling.

The effects of RA in normal heart have been previously studied. In an animal model, our group [18] studied the cardiac effects of RA in normal rats for 90 days. The animals treated with RA developed an increase in $\mathrm{LV}$ mass, assessed by myocyte CSA, without change in the myocardial collagen volume fraction. Importantly, our results produced still two

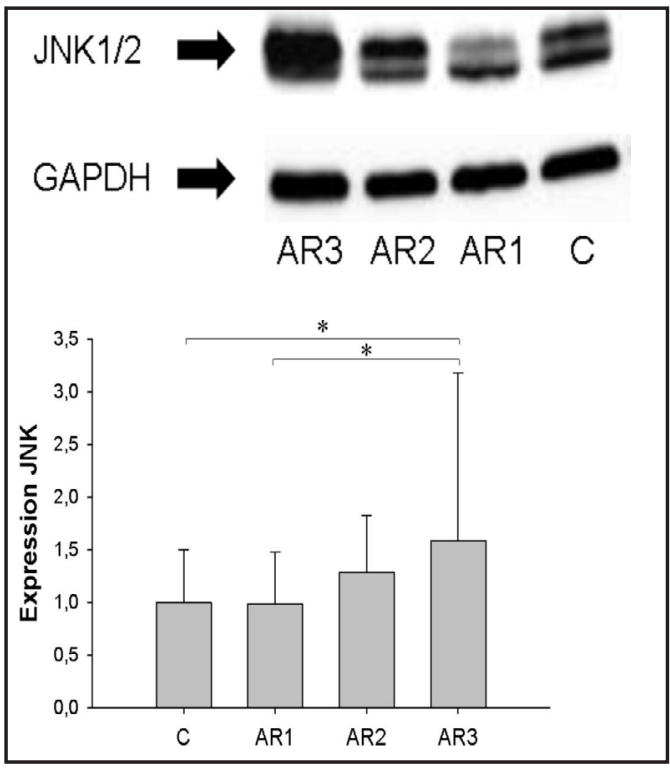
questions: Is the remodeling process induced by RA physiologic or pathologic? And does this comportment occur in humans? Therefore, our next step was to analyze the effects of RA in humans. For more than 25 years, RA has been used for the treatment of acne. Thus, we studied the cardiac effects of patients with acne receiving 13-cys-RA [19]. After 10 weeks of therapy, patients showed reductions in right atrium diameter and LV diastolic diameter, associated with increases in interventricular septum diastolic thickness, relative wall thickness, and LV mass. The cardiac function did not change with the treatment. Therefore, we concluded that RA induced cardiac remodeling in humans. However, it was unknown whether remodeling induced by RA was physiologic or pathologic in this scenario.

For the purpose of removing doubt of whether the cardiac effects of RA are characteristic of physiologic or pathologic adaptations, we conducted this study, analyzing the consequences of RA supplementation on morphological and functional variables, energy metabolism, oxidative stress, and signaling pathways. Our results demonstrated that RA, added to a 


\section{Cellular Physiology Cell Physiol Biochem 2017;43:1449-1459

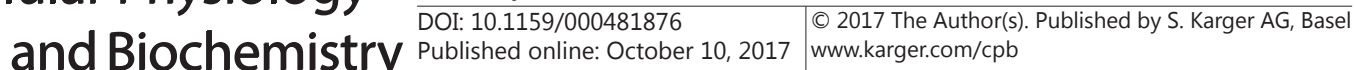 \\ Silva et al.: Retinoic Acid and Ventricular Remodeling}

normal rat chow diet, induced myocardial hypertrophy, as assessed by CSA. Regardless of the complexity of the remodeling process, it is well established that myocardium hypertrophy plays a key role on cardiac remodeling [28]. Interestingly, LV function was preserved with the treatment. Thus, morphological and functional variables did not help to distinguish the process as adaptative or deleterious. However, in different models of remodeling, it is accepted that biochemical, molecular and cellular alterations precede the morphological and functional alterations. Therefore, we hypothesized that, with longer follow-up, exposure to retinoic acid would induce functional alterations.

Thus, the first variable used to differentiate the process of remodeling as physiologic or pathologic was the cardiac energy metabolism. Under normal conditions, fatty acids are the main substrates used by mitochondria to provide myocardial energy. During heart remodeling, however, the fuel preference switches to glucose [29-31]. Our study showed that supplementation with RA was associated with a reduction of the enzymes of fatty acid metabolism associated with an increase of enzymes involved in glucose use. In addition, a reduction of citrate synthase and ATP synthase was observed in animals that were supplemented with RA, suggesting reduction in the use of energy substrate. Therefore, the changes found in energy metabolism are characteristic of deleterious remodeling situations.

The second variable used to discern remodeling induced by RA as physiologic or pathologic was oxidative stress. Oxidative stress may act in cell membranes, causing lipid peroxidation, as in the nucleus as well as interfering with DNA and RNA synthesis, leading to cell damage that alters the functional and structural cardiac variables. At normal situations, cells have antioxidant systems to hold the accumulation of ROS [32]. Our results demonstrated that the rats supplemented with RA showed changes in antioxidant enzyme values. Importantly, we infer that the treatment induces oxidative stress because the $\mathrm{LH}$ levels were increased in the supplemented animals in a dose-dependent manner. Therefore, cardiac remodeling induced by RA supplementation resulted in oxidative stress, suggesting deleterious adaptation.

Another important finding of the present investigation was that RA activated signaling pathways involved in pathologic cardiac remodeling. Several pathways that promote cell growth converge to the activation of mammalian target of rapamycin (mTOR) [33]. In fact, mTOR/S6K seems to be involved in pathologic remodeling [34-36] and mTOR/ PI3K/Akt seem to have a protective role [37-40]. Cardiac hypertrophy may be associated with the activation of other factors, including members of MAPKs [41-43], mainly associated with a pathologic pathway $[44,45]$. Our results showed the non-participation of complex mTOR and PI3K/Akt pathway in the heart supplemented by RA, suggesting that the remodeling process induced by RA has the characteristics observed in cases of pathologic cardiac hypertrophy.

The role of JNK pathway as a modulator of cardiac remodeling is less clear. Indeed, in different models, deleterious cardiac remodeling was associated with JNK activation. Likewise, transgenic activation of the JNK pathway in the heart resulted in pathologic remodeling associated with extracellular matrix alterations. On the other hand, deletion of JNK in the heart resulted in an increase in fibrosis following pressure overload. Similarly, chronic treatment with a JNK inhibitor led to increased apoptosis and cardiac fibrosis in the cardiomyopathic hamster model [45]. Taken together, these findings indicate that, although usually involved in pathological processes, JNK activation is most likely a dynamic signaling event that can be influenced by the nature of the stimuli [45].

Finally, our study should be interpreted taking into account some important aspects. As discussed previously, upregulation of JNK1/2 by itself does not indicate a pathological remodeling response. JNK1/2 is involved in a number of cardiac remodeling pathways and has different downstream effectors dependent on the upregulating signal involved. Therefore, it is important to emphasize that our conclusion is not based solely on JNK findings. Our interpretation is based on upregulation of JNK, associated with normal values of different physiological pathways, along with changes in oxidative stress and energy metabolism suggesting pathologic remodeling. 


\section{Cellular Physiology Cell Physiol Biochem 2017;43:1449-1459 \begin{tabular}{l|l|l} 
DOI: 10.1159/000481876 & $\begin{array}{l}\text { O 2017 The Author(s). Published by S. Karger AG, Basel } \\
\text { www.karger.com/cpb }\end{array}$ \\
\hline
\end{tabular}

In conclusion, in normal rats, RA induces cardiac hypertrophy, in a dose-response manner. The non-participation of the PI3K/Akt pathway, associated with the participation of the JNK pathway, oxidative stress, and changes in energy metabolism, suggests that cardiac remodeling induced by RA supplementation is deleterious.

\section{Disclosure Statement}

Nothing to delare.

\section{Acknowledgements}

This work was supported by Fundação de Amparo à Pesquisa do Estado de São Paulo (FAPESP: 2012/21186-2).

\section{References}

-1 Narematsu M, Kamimura T, Yamagishi T, Fukui M, Nakajima Y: Impaired development of left anterior heart field by ectopic retinoic acid causes transposition of the great arteries. J Am Heart Assoc 2015;30:1-11.

-2 Shen H, Cavallero S, Estrada KD, Sandovici I, Kumar SR, Makita T, Lien CL, Constancia M, Sucov HM: Extracardiac control of embryonic cardiomyocyte proliferation and ventricular wall expansion. Cardiovasc Res 2015;105:271-278.

3 Pan J, Baker KM: Retinoic acid and the heart. Vitam Horm 2007;75:257-283.

-4 Xavier-Neto J, Sousa Costa ÂM, Figueira AC, Caiaffa CD, Amaral FN, Peres LM, da Silva BS, Santos LN, Moise AR, Castillo HA: Signaling through retinoic acid receptors in cardiac development: doing the right things at the right times. Biochim Biophys Acta 2015;1849:94-111.

-5 Shenefelt RE: Morphogenesis of malformations in hamsters caused by retinoic acid-relation to dose and stage at treatment. Teratology 1972;5:103-118.

-6 Colbert MC, Kirby ML, Robbins J: Endogenous retinoic acid signaling colocalizes with advanced expression of the adult smooth muscle myosin heavy chain isoform during development of the ductus arteriosus. Circ Res 1996;78:790-798.

7 Colbert MC, Hall DG, Kimball TR, Witt SA, Lorenz JN, Kirby ML, Hewett TE, Klevitsky R, Robbins J: Cardiac compartment-specific overexpression of a modified retinoic acid receptor produces dilated cardiomyopathy and congestive heart failure in transgenic mice. J Clin Invest 1997;100:1958-1968.

8 Subbarayan V, Mark M, Messadeq N, Rustin P, Chambon P, Kastner P: RXR alpha overexpression in cardiomyocytes causes dilated cardiomyopathy but fails to rescue myocardial hypoplasia in RXR alpha-null fetuses. J Clin Invest 2000;105:387-394.

-9 Dyson E, Sucov HM, Kubalak SW, Schmidschonbein GW, Delano FA, Evans RM, Ross J Jr, Chien KR: Atrial-like phenotype is associated with embryonic ventricular failure in retinoid-X receptor- / mice. Proc Natl Acad Sci USA 1995;92:7386-7390.

10 Xu Y, Gao AM, Ji LJ, Li X, Zhong LL, Li HL, Zheng DH: All-trans retinoic acid attenuates hypoxia-induced injury in NRK52E cells via inhibiting NF-x03BA;B/VEGF and TGF- $\beta 2 / V E G F$ pathway. Cell Physiol Biochem. 2016;38:229-236.

11 Xu WX, Liu SZ, Wu D, Qiao GF, Yan J: Sumoylation of the tumor suppressor promyelocytic leukemia protein regulates arsenic trioxide-induced collagen synthesis in osteoblasts. Cell Physiol Biochem. 2015;37:1581-1591.

12 Lu L, Yao T, Zhu YZ, Huang GY, Zhu YC: Chronic all-trans retinoic acid treatment prevents medial thickening of intramyocardial and intrarenal arteries in spontaneously hypertensive rats. Am J Physiol Heart Circ Physiol 2003;285: H1370-H1377.

13 Oliveira LC, Azevedo PS, Minicucci ME, Rafacho BP, Duarte DR, Matsubara LS, Matsubara BB, Paiva SA, Zornoff LA: Retinoic acid prevents ventricular remodelling induced by tobacco smoke exposure in rats. Acta Cardiol 2011;66:3-7. 


\section{Cellular Physiology Cell Physiol Biochem 2017;43:1449-1459

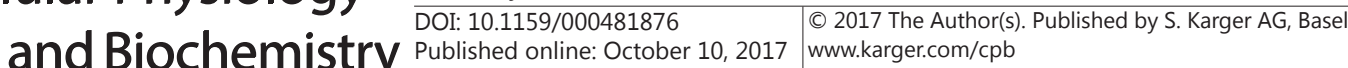

Silva et al.: Retinoic Acid and Ventricular Remodeling

14 Paiva SA, Matsubara LS, Matsubara BB, Minicucci MF, Azevedo PS, Campana AO, Zornoff LA: Retinoic acid supplementation attenuates ventricular remodeling after myocardial infarction in rats. J Nutr 2005;135:2326-2328.

15. Bilbija D, Haugen F, Sagave J, Baysa A, Bastani N, Levy FO, Sirsjö A, Blomhoff R, Valen G: Retinoic acid signalling is activated in the postischemic heart and may influence remodelling. PLoS One 2012;7:e44740.

16 Choudhary R, Palm-Leis A, Scott RC, Guleria RS, Rachut E, Baker KM, Pan J: All-trans retinoic acid prevents development of cardiac remodeling in aortic banded rats by inhibiting the renin-angiotensin system. Am J Physiol Heart Circ Physiol 2008;294:H633-H644.

$\checkmark 17$ Gregory EK, Webb AR, Vercammen JM, Flynn ME, Ameer GA, Kibbe MR: Periadventitial atRA citrate-based polyester membranes reduce neointimal hyperplasia and restenosis after carotid injury in rats. Am J Physiol Heart Circ Physiol 2014;15:H1419-H1429.

18 Paiva SAR, Zornoff LA, Okoshi MP, Okoshi K, Matsubara LS, Matsubara BB, Cicogna AC, Campana AO: Ventricular remodeling induced by retinoic acid supplementation in adult rats. Am J Physiol Heart Circ Physiol 2003;284:H2242-H2246.

19 Soriano EA, Azevedo PS, Miot HA, Minicucci MF, Pansani MC, Matsubara LS, Okoshi K, Zornoff LA, Matsubara BB, Paiva SA: Cardiac remodeling induced by 13-cis retinoic acid treatment in acne patients. Int J Cardiol 2013;163:68-71.

20 Lang RM, Bierig M, Devereux RB, Flachskampf FA, Foster E, Pellikka PA, Picard MH, Roman MJ, Seward J, Shanewise J, Solomon S, Spencer KT, John Sutton MS, Stewart W: Recommendations for chamber quantification: a report from the American Society of Echocardiography's Guidelines and Standards Committee and the Chamber Quantification Writing Group, developed in conjunction with the European Association of Echocardiography, a branch of the European Society of Cardiology. J Am Soc Echocardiogr 2005;18:1440-1463.

-21 Gonçalves AF, Congio LH, dos Santos PP, Rafacho BP, Pereira BL, Claro RF, Costa NA, Chiuso-Minicucci F, Azevedo PS, Polegato BF, Okoshi K, Pereira EJ, Okoshi MP, Paiva SA, Zornoff LA, Minicucci MF: Pamidronate attenuates diastolic dysfunction induced by myocardial infarction associated with changes in geometric patterning. Cell Physiol Biochem 2015;35:259-269.

22 Polegato BF, Minicucci MF, Azevedo PS, Carvalho RF, Chiuso-Minicucci F, Pereira EJ, Paiva SA, Zornoff LA, Okoshi MP, Matsubara BB, Matsubara LS: Acute doxorubicin-induced cardiotoxicity is associated with matrix metalloproteinase-2 alterations in rats. Cell Physiol Biochem 2015;35:1924-1933.

-23 Azevedo PS, Minicucci MF, Chiuso-Minicucci F, Justulin LA Jr, Matsubara LS, Matsubara BB, Novelli E, Seiva F, Ebaid G, Campana AO, Zornoff LA, Paiva SA: Ventricular remodeling induced by tissue vitamin A deficiency in rats. Cell Physiol Biochem 2010;26:395-402.

24 Minicucci MF, Azevedo PS, Oliveira SA Jr, Martinez PF, Chiuso-Minicucci F, Polegato BF, Justulin LA Jr, Matsubara LS, Matsubara BB, Paiva SA, Zornoff LA: Tissue vitamin A insufficiency results in adverse ventricular remodeling after experimental myocardial infarction. Cell Physiol Biochem 2010;26:523-530.

25 Paiva SAR, Novo R, Matsubara BB, Matsubara LS, Azevedo PS, Minicucci MF, Campana AO, Zornoff LAM: $\beta$-Carotene attenuates the paradoxical effect of tobacco smoke on the mortality of rats after experimental myocardial infarction. J Nutr 2005;135:2109-2113.

-26 Santos PP, Oliveira F, Ferreira VC, Polegato BF, Roscani MG, Fernandes AA, Modesto P, Rafacho BP, Zanati SG, Di Lorenzo A, Matsubara LS, Paiva SA, Zornoff LA, Minicucci MF, Azevedo PS: The role of lipotoxicity in smoke cardiomyopathy. PLoS One 2014;9:e113739.

-27 Assalin HB, Rafacho BP, dos Santos PP, Ardisson LP, Roscani MG, Chiuso-Minicucci F, Barbisan LF, Fernandes AA, Azevedo PS, Minicucci MF, Zornoff LA, de Paiva SA: Impact of the length of vitamin D deficiency on cardiac remodeling. Circ Heart Fail 2013;6:809-816.

28 Azevedo PS, Polegato BF, Minicucci MF, Paiva SA, Zornoff LA: Cardiac remodeling: concepts, clinical impact, pathophysiological mechanisms and pharmacologic treatment. Arq Bras Cardiol 2016;106:62-69.

29 Doenst T, Nguyen TD, Abel ED: Cardiac metabolism in heart failure: implications beyond ATP production. Circ Res 2013;113:709-724.

-30 Azevedo PS, Minicucci MF, Santos PP, Paiva SA, Zornoff LA: Energy metabolism in cardiac remodeling and heart failure. Cardiol Rev 2013;21:135-140.

-31 Stanley WC, Recchia FA, Lopaschuk GD: Myocardial substrate metabolism in the normal and failing heart. Physiol Rev 2005;85:1093-1129. 


\section{Cellular Physiology Cell Physiol Biochem 2017;43:1449-1459

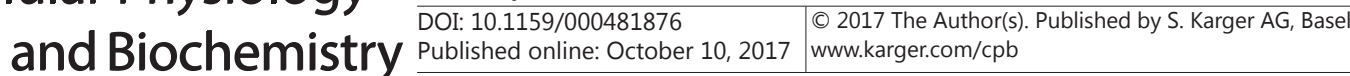

-32 Sawyer DB, Siwik DA, Xiao L, Pimentel DR, Singh K, Colucci WS: Role of oxidative stress in myocardial hypertrophy and failure. J Moll Cell Cardiol 2002;34:379-388.

-33 Shende P, Plaisance I, Morandi C, Pellieux C, Berthonneche C, Zorzato F, Krishnan J, Lerch R, Hall MN, Rüegg MA, Pedrazzini T, Brink M: Cardiac raptor ablation impairs adaptive hypertrophy, alters metabolic gene expression, and causes heart failure in mice. Circulation 2011;123:1073-1082.

-34 Senbonmatsu T, Ichihara S, Price E, Gaffney FA, Inagami T: Evidence for angiotensin II type 2 receptormediated cardiac myocyte enlargement during in vivo pressure overload. J Clin Invest 2000;106:R25-R29.

-35 Iijima Y, Laser M, Shiraishi H, Willey CD, Sundaravadivel B, Xu L, McDermott PJ, Kuppuswamy D: c-Raf/ MEK/ERK pathway controls protein kinase C-mediated p70S6K activation in adult cardiac muscle cells. J Biol Chem 2002;277:23065-23075.

-36 Shioi T, McMullen JR, Tarnavski O, Converso K, Sherwood MC, Manning WJ, Izumo S: Rapamycin attenuates load-induced cardiac hypertrophy in mice. Circulation 2003;107:1664-1670.

37 Jacinto E, Loewith R, Schmidt A, Lin S, Rüegg MA, Hall A, Hall MN: Mammalian TOR complex 2 controls the actin cytoskeleton and is rapamycin insensitive. Nat Cell Biol 2004;6:1122-1128.

-38 Sarbassov DD, Ali SM, Kim DH, Guertin DA, Latek RR, Erdjument-Bromage H, Tempst P, Sabatini DM: Rictor, a novel binding partner of mTOR, defines a rapamycin-insensitive and raptor-independent pathway that regulates the cytoskeleton. Curr Biol 2004;14:1296-1302.

39 Corradetti MN, Guan KL: Upstream of the mammalian target of rapamycin: do all roads pass through mTOR? Oncogene 2006;25:6347-6660.

40 Kemi OJ, Ceci M, Wisloff U, Grimaldi S, Gallo P, Smith GL, Condorelli G, Ellingsen O: Activation or inactivation of cardiac Akt/mTOR signaling diverges physiological from pathological hypertrophy. J Cell Physiol 208;214:316-321.

41 Bueno OF, De Windt LJ, Tymitz KM, Witt SA, Kimball TR, Klevitsky R, Hewett TE, Jones SP, Lefer DJ, Peng CF, Kitsis RN, Molkentin JD: The MEK1-ERK1/2 signaling pathway promotes compensated cardiac hypertrophy in transgenic mice. EMBO J 2000;19:6341-6350.

-42 Aikawa R, Komuro I, Nagai R, Yazaki Y: Rho plays an important role in angiotensin II-induced hypertrophic responses in cardiac myocytes. Mol Cell Biochem 2000;212:177-182.

43 Minamino T, Yujiri T, Terada N, Taffet GE, Michael LH, Johnson GL, Schneider MD: MEKK1 is essential for cardiac hypertrophy and dysfunction induced by Gq. Proc Natl Acad Sci USA 2002;19:3866-3871.

44 Barry SP, Davidson SM, Townsend PA: Molecular regulation of cardiac hypertrophy. Int J Biochem Cell 2008;40:2023-2039.

45 Rose BA, Force T, Wang Y: Mitogen-activated protein kinase signaling in the heart: angels versus demons in a heart-breaking tale. Physiol Rev 2010;90:1507-1546. 